\title{
The value of CRP, IL-6, leptin, cortisol, and peritoneal caspase-3 monitoring in the operative strategy of secondary peritonitis
}

\author{
Sekonder peritonitte planlı abdominal onarımın sonlandırılma kararında \\ C reaktif protein, interlökin 6, leptin, kortizol ve kaspaz 3 değerlerinin etkisi \\ Faruk PEHLIVANLI, ${ }^{1}$ Fatih AĞALAR, ${ }^{1}$ Canan AĞLAR,${ }^{2}$ Oral SAYGUN, ${ }^{1}$ Cağatay DAPHAN, ${ }^{1}$ \\ Kuzey AYDINURAZ, ${ }^{1}$ Unase BÜYÜKKOÇAK, ${ }^{3}$ Osman ÇAĞLAYAN, ${ }^{4}$ Sedat DOM, ${ }^{1}$ Tayfun ŞAHİNER ${ }^{1}$
}

\section{BACKGROUND}

We aimed to investigate the impact of C-reactive protein (CRP), interleukin (IL)-6, leptin, cortisol, and caspase-3 on the decision of terminating planned abdominal repair in secondary peritonitis.

\section{METHODS}

Fifteen patients with peritonitis were enrolled into the study. Serum CRP, IL-6, leptin, cortisol, and peritoneal caspase-3 activities were measured.

\section{RESULTS}

APACHE II scores at 48 hours (h) and age were significantly higher in non-survivors. A significant decrease was observed in caspase- 3 activities of patients in whom $\leq 4$ laparotomies were performed when compared with those who underwent $>4$ laparotomies. For patients who underwent $\leq 4$ laparotomies, there was a significant difference in caspase- 3 levels between 0 and $72 \mathrm{~h}$. There was no significant difference in caspase-3 levels in non-survivors; caspase-3 levels were significantly lower in the survivors at 48 and $72 \mathrm{~h}$. Changes in CRP, IL-6, leptin, and cortisol levels were not statistically significant.

\section{CONCLUSION}

CRP, IL-6, leptin, cortisol, and caspase-3 are not valuable in discriminating the number of planned operations, even though there is a significant decrease in caspase-3 "within" survivors. The discriminative value of caspase-3 for closure should be evaluated in studies in which caspase- 3 is monitored for a longer duration in a large number of patients.

Key Words: Caspase-3; peritonitis; planned relaparotomy; interleukin-6; cortisol.

\section{$A M A C$}

Orta ve ciddi sekonder peritonitte planlı abdominal onar1mın sonlandırılma kararında $\mathrm{C}$ reaktif protein (CRP), interlökin (IL) 6, leptin, kortizol ve kaspaz 3 değerlerinin etkisi araştırıldı.

\section{GEREÇ VE YÖNTEM}

Orta ve ciddi sekonder peritonitli 15 hasta alındı. Serum CRP, IL-6, leptin ve kortizol düzeyleri ile periton sıvılarında kaspaz 3 ölçüldü.

\section{BULGULAR}

Mortalite gelişenlerde yaş ve 48. saat APACHE II skoru, gelişmeyenlere göre anlamlı olarak yüksek olarak bulundu. Tüm gruplarda 0 . saat ve 72 . saat kaspaz düzeyleri arasında anlamlı fark bulundu. Dörtten az ve fazla yıkama yapılanlar kaspaz açısından karşılaştırıldığında; az yıkama yapılanlarda kaspaz değerlerinde azalma olduğu izlendi. Dört ve daha az yıkama yapılanlarda 0 . saat kaspaz ile 72 . saat kaspaz değerleri arasında anlamlı farklılık bulundu. Mortalite olan grubun kaspaz 3 değerleri arasında farklılık saptanmazken, mortalite olmayan grupta kaspaz 3 48. ve 72. saat değerlerinde anlamlı bir düşüş izlendi. CRP, IL-6, leptin ve kortizol seviyelerindeki değişiklikler anlamlı bulunmadı.

\section{SONUÇ}

CRP, IL-6, leptin, kortizol seviyesinin karın kapatılması kararında etkisinin olmadığg görülmüştür. Kaspaz 3 seviyelerindeki düşüş yıkama sayısını belirlemede yararlı olabilir. Karın kapamada yıkama sayısını belirlemede vekil parametre olarak kaspaz 3 seçilecekse, daha uzun sürelerdeki kaspaz aktivitesini değerlendiren çalışmalara ihtiyaç vardır.

Anahtar Sözcükler: Kaspaz 3; peritonit; planlı repalarotomi; interlökin 6; kortizol.
Departments of ${ }^{1}$ General Surgery, ${ }^{2}$ Infectious Diseases and Clinical Microbiology, ${ }^{3}$ Anesthesiology and Reanimation,

${ }^{4}$ Biochemistry, Kirikkkale University Faculty of Medicine, Kirikkale, Turkey.
Kırıkkale Üniversitesi Tıp Fakültesi, ${ }^{1}$ Genel Cerrahi Anabilim Dalı,

${ }^{2}$ Enfeksiyon Hastalıkları ve Klinik Mikrobiyoloji Anabilim Dalı,

${ }^{3}$ Anesteziyoloji ve Reanimasyon Anabilim Dalı, ${ }^{4}$ Biyokimya Anabilim Dalı, Kirikkale. 
Among peritonitis, secondary peritonitis is the most frequently encountered intraabdominal infection, with high mortality and morbidity. Surgical source control and peritoneal toilets help peritoneal and systemic host defense mechanisms, which are the important steps in the treatment of this disease. $[1-3 \mid$ Today, on-demand laparotomy is accepted as the standard therapy of peritonitis, but various types of open abdominal procedures are also advocated in selected cases. ${ }^{[4-7]}$ Recently, Lamme et al. ${ }^{[8]}$ showed in a prospective randomized study that on-demand laparotomy is superior to planned relaparotomy in terms of hospital stay and morbidity. They found no mortality rate difference between planned relaparotomy and the on-demand group, but the morbidity rate was high and hospital stay was longer in the former. Rakic et al. ${ }^{[9]}$ reached a similar conclusion in another prospective clinical study. Recently, an Amsterdam group showed the superiority of on-demand laparotomy to planned operations in terms of cost. ${ }^{[10]}$ Costs were substantially lower in the on-demand group.

The findings of these recent studies led us to use open abdominal approaches with more caution in the treatment of peritonitis.

The increased morbidity and hospital stay may be due to the number of relaparotomies rather than the procedure itself. Since surgical trauma produces an immune depression and causes a depressed woundhealing process, a well-balanced surgical therapy should be achieved. ${ }^{[11-13]}$ Thus, it is crucial to terminate the procedure by definitive closure with an optimum number of relaparotomies. Yet, there is no valid or measurable surrogate parameter in the estimation of the optimum number of planned operations.

Generalization of the results to the community at large is one of the main problems of a randomized controlled study, and the problem is more evident in the case of peritonitis. Today and in the near future, various types of open abdominal approaches will probably be used by some surgeons in selected cases.

Some interesting interactions between caspases and peritoneal host defenses were observed in animal models of sepsis. It was shown before that there was a marked increase in apoptosis in endotoxin-stimulated phagocytes, which was associated with a significant increase in caspase- $3,-8$ and -9 activities. ${ }^{[14]}$ Apoptosis occurred 24 hours (h) after the onset of peritonitis in an animal model of sepsis. ${ }^{[15]}$ Thus, it is logical to explore the activity of caspase- 3 in the initial phase in the clinical setting. There is also a clear-cut correlation between caspase-3 levels and peritoneal mesothelial cell apoptosis. ${ }^{[16]}$ With the above- mentioned literature data, monitoring of peritoneal fluid caspase levels in the treatment of peritonitis may add valid data to our clinical knowledge.
Therefore, the aim of this prospective study was to evaluate the effects of initial three-day monitoring of plasma C-reactive protein (CRP), interleukin (IL)-6, cortisol, leptin, and peritoneal fluid caspase-3 levels on the management of planned relaparotomies and the factors affecting severity and mortality.

\section{MATERIALS AND METHODS}

This prospective study was conducted in the Department of General Surgery, Kirikkale University School of Medicine. This study was approved by the Ethical Committee of Kirikkale University.

Patients having secondary peritonitis and Acute Physiology and Chronic Health Evaluation (APACHE) II scores of $\geq 10$ were included. Because APACHE II score works well in determining the severity in peritonitis, initial and second day scores were recorded in the present study. ${ }^{[17,18]}$

\section{Inclusion criteria:}

1. Patients older than 16 years

2. Patients having secondary peritonitis with APACHE II score of $\geq 10$

\section{Exclusion criteria:}

1. Patients who prefer "on-demand laparotomy"

2. Patients who will probably die within $24 \mathrm{~h}$ and are unresponsive to shock therapy

3. Patients with primary peritonitis

4. Patients having massive mesenteric vascular occlusions

5. Patients having pancreatitis (Due to the facts that pancreatitis has quite distinct physiopathological aspects from secondary peritonitis, and the types of the planned operations are different from those performed for secondary peritonitis)

\section{Parameters:}

1. Demographic variables

2. Complete blood count, blood chemistry, APACHE II, blood CRP, IL-6, cortisol, and leptin levels

\section{Peritoneal fluid caspase-3 levels}

Under standard anesthesia, median laparotomy was done. Source control was achieved with ostomies when possible. The peritoneal space was washed with 2-3 liters of warm saline. Standard anastomotic techniques with conventional double-layer suture methods were applied. Stapling devices were used where appropriate. If possible, the omentum was preserved during operations, because omentectomy depresses not only peritoneal defense mechanisms such as chemotactic activity of leukocytes and neutrophil phagocytosis, but also the number of free peritoneal fluid macrophages and leukocytes. ${ }^{[13]}$ It also protects the bowels from foreign body so-called "Bogota bag" dur- 
Table 1. Pathologies and the outcome of patients

\begin{tabular}{lccc}
\hline Etiology of peritonitis & Alive & Exitus & Total \\
\hline Small bowel perforation & 2 & 1 & 3 \\
Colonic perforation & 3 & 0 & 3 \\
Perforated appendicitis & 1 & 0 & 1 \\
Anastomotic failure & 2 & 2 & 4 \\
Retroperitoneal necrotizing fasciitis & 1 & 0 & 1 \\
Gastric perforation & 1 & 0 & 1 \\
Suture failure and infection & & & \\
after myomectomy & 1 & 0 & 1 \\
Intestinal obstruction & 0 & 1 & 1 \\
Total & 11 & 4 & 15 \\
\hline
\end{tabular}

ing planned relaparotomies. The Bogota bag was used for temporary closure of the abdominal cavity after the index operation. The interval between operations was one day. The procedures were terminated according to surgeon's decision, and definitive closure was performed using heavy propylene sutures. We did not intend to definitively close the fascial planes if the length of the overall procedure exceeded 10 days. Some sort of late abdominal closure techniques were applied in those patients.

During the first four laparotomies, blood samples (including index operation) for routine biochemistry, CRP, IL-6, leptin, and cortisol and peritoneal fluid samples for caspase-3 activities were obtained. Peritoneal fluid samples were obtained after the onset of laparotomy, or relaparotomy from 4 quadrants and interloop spaces. A homogenization was performed before the sample was transferred to the laboratory.

Latex immunoturbidimetric assay for CRP (Olympus AU600, Olympus Optical Co. Ltd., Japan) was done. IL-6 assays were performed using Biosource Immunoassay kit human IL-6 (Biosource International, Inc., USA). For leptin, Biosource Leptin Easia kit was used (Biosource Europe, S. A. Nivelles, Belgium). Cortisol levels were assessed by electrochemiluminescence immunoassay (Roche e170 Modular Analytics, Hitachi, Japan). Caspase was assessed using Human Caspase-3 Instant ELISA (Bender Med Systems, Vienna, Austria).

Microbiological studies: Standard microbiological cultures were obtained and standard microbiologic surveillance was carried out.

Antibiotic treatment: Empirical antibiotic treatment was given initially and changed if needed according to culture results. Carbapenems: Mostly meropenem (3x1 g IV), or imipenem (4x500 mg IV) was used at least 10 days. APACHE II scores of the first and second days were recorded.

\section{Statistical Analysis}

SPSS 17.0 was used for statistical analysis. Chisquare test was used for descriptive statistics, incidences and for univariate analysis of factors affecting mortality. Student's t-test was used for analysis of parametric data, whereas Mann-Whitney U test was used for analysis of nonparametric data. Min-max was used for central dispersion measures of nonparametric tests and $\pm \mathrm{SD}$ for parametric tests. Spearman's correlation test was used for correlation between parameters. Friedman and Wilcoxon Signed Rank tests were applied for intraparametric changes. Values of $p<0.05$ were accepted as statistically significant.

\section{RESULTS}

Nine of 15 patients included in the study were male. The median age of the patients was 58 (23-79) years. Four of the patients had anastomotic failure (Table 1).

There was no growth in any cultures in 4 of 15 patients. Five patients had Escherichia coli, 3 had Pseudomonas aeruginosa, 3 had coagulase (-) Staphylococcus, 2 had Acinetobacter spp, and 7 had Candida

Table 2. The demographic variables of patients

\begin{tabular}{lcccccccc}
\hline No & Age & Gender & Mortality & APACHE II $(0 \mathrm{~h})$ & APACHE II $(48 \mathrm{~h})$ & Hospital stay/day & ICU day & Number of operations \\
\hline 1 & 55 & M & No & 16 & 11 & 26 & 16 & 5 \\
2 & 23 & F & No & 11 & 7 & 12 & 1 & 4 \\
3 & 79 & F & Yes & 27 & 28 & 45 & 45 & 12 \\
4 & 39 & F & No & 10 & 9 & 12 & 4 & 4 \\
5 & 45 & M & No & 10 & 7 & 11 & 4 & 4 \\
6 & 75 & M & No & 14 & 11 & 32 & 6 & 4 \\
7 & 78 & M & Yes & 26 & 22 & 20 & 20 & 4 \\
8 & 72 & F & No & 16 & 15 & 33 & 5 & 4 \\
9 & 70 & M & No & 14 & 11 & 36 & 7 & 4 \\
10 & 72 & F & Yes & 14 & 16 & 13 & 13 & 5 \\
11 & 44 & M & No & 15 & 12 & 22 & 22 & 8 \\
12 & 49 & M & No & 10 & 10 & 41 & 15 & 7 \\
13 & 52 & M & No & 18 & 7 & 48 & 22 & 4 \\
14 & 65 & F & No & 20 & 13 & 19 & 7 & 4 \\
15 & 58 & M & Yes & 15 & 16 & 3 & 3 & 3 \\
\hline
\end{tabular}


Table 3. The differences between survivors and non-survivors

\begin{tabular}{|c|c|c|c|}
\hline Parameter & Alive $(\mathrm{n}=11)$ & Exitus $(\mathrm{n}=4)$ & $\mathrm{p}$ \\
\hline Age & $52(23-75)$ & $75(58-79)$ & 0.026 \\
\hline APACHE II (initial) & $14(10-20)$ & $20(14-27)$ & 0.13 \\
\hline APACHE II (48 h) & $11(7-15)$ & $19(16-28)$ & 0.001 \\
\hline Hospital stay (day) & $26(11-48)$ & $16(3-45)$ & 0.06 \\
\hline ICU stay (day) & $7(1-22)$ & $16(3-45)$ & 0.075 \\
\hline Number of operations & $4(4-8)$ & $4(3-12)$ & 0.66 \\
\hline Cortisol (initial) $\mu \mathrm{g} / \mathrm{dl}$ & $849.8(189.3-1897)$ & $987.3(218.2-1342)$ & 0.79 \\
\hline Cortisol (24 h) $\mu \mathrm{g} / \mathrm{dl}$ & $845.9(188.8-1616)$ & $884(725.6-1458)$ & 0.89 \\
\hline Cortisol (48 h) $\mu \mathrm{g} / \mathrm{dl}$ & 735 (194.6-1582) & $855.5(217-1400)$ & 0.74 \\
\hline Cortisol (72 h) $\mu \mathrm{g} / \mathrm{dl}$ & $858.9(196.5-1654)$ & $904.6(196.5-945.7)$ & 0.64 \\
\hline CRP (initial) mg/L & $190.85(23.48-199.88)$ & $187.78(34.31-200.04)$ & 0.79 \\
\hline CRP $(24$ h) mg/L & $187.26(23.04-201.11)$ & $196.41(191.53-198.97)$ & 0.19 \\
\hline $\mathrm{CRP}(48 \mathrm{~h}) \mathrm{mg} / \mathrm{L}$ & $181.86(23.44-200.52)$ & $165.77(34.85-185.82)$ & 0.36 \\
\hline $\mathrm{CRP}(72 \mathrm{~h}) \mathrm{mg} / \mathrm{L}$ & $182.74(23.69-197.4)$ & $134.64(23.93-169.94)$ & 0.10 \\
\hline IL-6 (initial) $\mathrm{pg} / \mathrm{ml}$ & $179.1(22.3-18500)$ & $303.2(10.2-876.8)$ & 0.51 \\
\hline IL-6 (24 h) pg/ml & $145.3(5.70-948.1)$ & $640.65(48.7-18500)$ & 0.19 \\
\hline IL-6 (48 h) pg/ml & $164(5.5-19000)$ & $470.75(51.4-1003.4)$ & 0.51 \\
\hline IL-6 (72 h) pg/ml & $81.8(11.9-22000)$ & $585.00(54.3-645.7)$ & 0.39 \\
\hline Leptin (initial) $\mathrm{ng} / \mathrm{ml}$ & $2.99(1.27-40.59)$ & $4.63(1.27-5.5)$ & 0.39 \\
\hline Leptin (24 h) ng/ml & $2.8(1.08-60.42)$ & $3.18(1.84-4.54)$ & 0.89 \\
\hline Leptin (48 h) ng/ml & $3.76(1.84-30)$ & $2.99(1.65-145.09)$ & 0.64 \\
\hline Leptin (72 h) ng/ml & $4.92(1.84-156.86)$ & $3.95(2.8-10.55)$ & 0.35 \\
\hline Caspase-3 (initial) & $47.84(3.77-479.3)$ & $28.24(8.07-110.53)$ & 0.51 \\
\hline Caspase-3 (24 h) & $28.76(6.68-272.89)$ & $28.15(22.96-469.66)$ & 0.43 \\
\hline Caspase-3 (48 h) & $18(4.73-77.19)$ & $31.22(7.98-306.18)$ & 0.36 \\
\hline Caspase-3 (72 h) & $12.79(5.67-137.94)$ & $14.15(9.84-38.64)$ & 0.69 \\
\hline WBC (initial) $\mathrm{mm}^{3}$ & $16300(2800-28200)$ & $7150(5100-19100)$ & 0.36 \\
\hline WBC (24 h) $\mathrm{mm}^{3}$ & $10000(3500-20600)$ & $9950(4100-22600)$ & 0.89 \\
\hline WBC (48 h) $\mathrm{mm}^{3}$ & $10200(4300-17600)$ & $11650(6000-22300)$ & 0.60 \\
\hline WBC (72 h) mm $\mathrm{mm}^{3}$ & $10500(4500-21600)$ & $5800(2200-16300)$ & 0.27 \\
\hline
\end{tabular}

Values are expressed as median (min-max). Normal values: CRP: 0-5 mg/L, IL-6: 720-1200 pg/ml, leptin: $2.4 \pm 1.1$ (females), $6.6 \pm 3$ (males) ng/ml, cortisol: $19 \mu \mathrm{g} / \mathrm{dl}$. WBC: White blood cell counts $/ \mathrm{mm}^{3}$.

spp growth in cultures. Antifungal therapy was not administered if the culture growth was regarded as colonization.

Mechanical ventilation was needed in 7 patients. The demographic variables of patients are presented in Table 2.

Initial, 24, 48 and $72 \mathrm{~h}$ caspase-3 levels of survivors and non-survivors did not differ (Table 3). Survivors were younger and second day APACHE II scores were lower (Table 3). Total hospital stay was longer and intensive care unit (ICU) stay was shorter in survivors (Table 3 ).

Caspase-3 levels in survivors: Initial, 24, 48. and 72 h peritoneal caspase-3 levels were 47.84 (3.77-479.3), 28.76 (6.68-272.89), 18 (4.73-77.19), 12.79 (5.67137.94), respectively. Peritoneal fluid caspase-3 levels showed a steep decline within 48 and $72 \mathrm{~h}(\mathrm{z}=2.76$, $\mathrm{p}=0.006 ; \mathrm{z}=2.67, \mathrm{p}=0.008$, respectively) (Fig. 1). However, no statistically significant decrease was found among initial, 24, 48, and $72 \mathrm{~h}$ caspase levels in non-survivors.

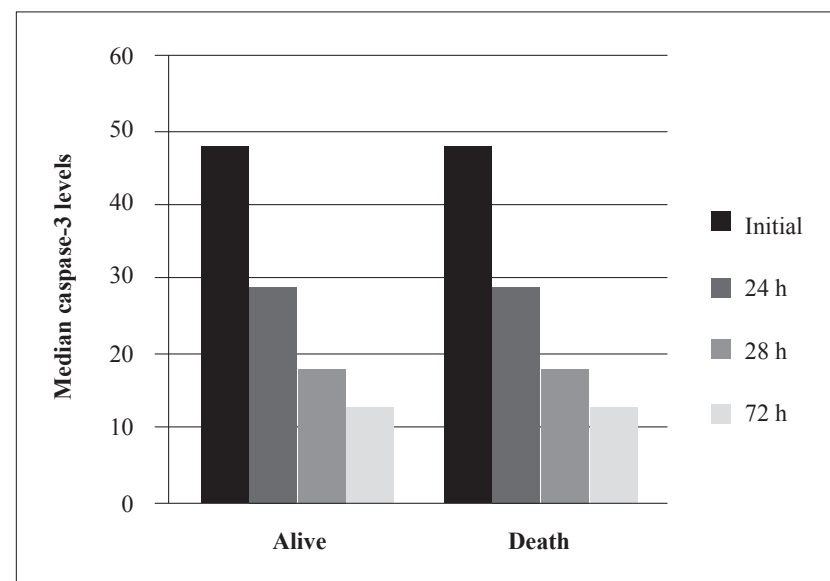

Fig. 1. Peritoneal caspase-3 levels within a 72-hour period in surviving patients.

Caspase-3 levels in survivors: Initial, 24, 48, and $72 \mathrm{~h}$ peritoneal caspase-3 levels were 47.8 (3.8-479), 28.8 (6.7-273), 18 (4.777.2), and 12.8 (5.7-138), respectively. Peritoneal fluid caspase-3 levels showed a steep decline within 48 and $72 h(z=2.76$, $p=0.006 ; z=2.67, p=0.008$, respectively). However, no statistically significant decrease was found among initial, 24, 48 and 72 h caspase levels in non-survivors. 
In patients who had undergone $\leq 4$ laparotomies, the initial and $72 \mathrm{~h}$ peritoneal caspase- 3 levels were $33.2(7.1-479)$ and $14.2(8.85-35.2)$, respectively $(\mathrm{z}=2.84, \mathrm{p}=0.004)$.

\section{DISCUSSION}

Despite recent advances in the diagnosis and management options, mortality and morbidity in peritonitis remain high. Surgical source control is vital in the treatment of sepsis originating from the abdomen. Despite rising concerns about planned relaparotomies in the treatment of peritonitis, ${ }^{[8,9,19]}$ its use in some selected cases may improve survival. ${ }^{[1,4,5,7]}$ The major concern for planned relaparotomy is related with its increased morbidity and hospital stay. It is important to avoid doing unnecessary laparotomies.

Because every laparotomy intent causes a further deterioration of peritoneal defense mechanisms, ${ }^{[3,12,13]}$ there should be a well-balanced surgical treatment. Although speculative, one can assume that the decrease in the number of relaparotomies may cause an increase in survival rates in some groups of patients who undergo a planned relaparotomy procedure.

Definitive closure of the abdominal wall is usually determined by using a very subjective criterion, the so-called "clean appearance of the abdominal cavity". Today, the optimal number of scheduled operations that should be done before a definitive closure is not yet sufficiently understood.

The authors of this present study aimed to determine a valid, helpful and measurable surrogate parameter that can be used in the decision-making process of planned relaparotomy.

A significant difference was found between second day APACHE II scores and mortality. Higher second day APACHE II scores were observed in non-survivors. This finding is in accordance with the findings of a study done by Lamme et al. ${ }^{[8]}$ In the present study, it was found that there was a correlation between the number of operations and hospital/ICU stay. This finding is also in accordance with the finding of Lamme et al. ${ }^{[8]}$

C-reactive protein (CRP) is an acute phase reactant, and its validity in estimating the prognosis in septic patients is not well known. There are conflicting results in the literature in this regard. For example, Silvestre et al. ${ }^{[20]}$ found in their study that CRP was not a good surrogate parameter for prognosis, and there was no good correlation between CRP levels and APACHE II scores. On the other hand, Prieto ${ }^{[21]}$ found that CRP is an important surrogate parameter of prognosis. In the present study, CRP levels were observed for three days. In general, initial CRP levels were higher than normal, but no significant alterations were observed in the consecutive days. We could not find any correlation between CRP levels and probability of mortality.

While endotoxic shock due to peritonitis causes a significant increase in leptin concentrations in animal models, ${ }^{[22]}$ in the clinical setting, decreased leptin levels correlate with increased mortality in patients suffering from severe secondary peritonitis. ${ }^{[23]}$ In the present study, leptin levels did not correlate well with APACHE II or the number of operations. High initial levels of leptin in non-survivors did not reach a statistically significant level. Keeping in mind the small number of events (deaths), we can assume that monitoring of leptin level is useless in the decision-making process in planned laparotomy for peritonitis.

In the present study, IL-6 levels were also measured, and no statistical difference was observed when patients were grouped as having high $(>10)$ or low APACHE II score. We reached the same conclusion of other researchers, i.e. that IL-6 is not helpful in predicting mortality in peritonitis patients. ${ }^{[24-26]}$

Controlling the septic source, peritoneal toilets and supportive measures such as fluid and antibiotic therapy certainly reverse the unfavorable peritoneal environment to a favorable one and restore a good recovery phase. A correlation between blood caspase levels and decrease in bacterial load in an animal model of peritonitis was shown before. ${ }^{[27]}$ If a good septic source control is not achieved, an ongoing peritoneal programmed cell death occurs. Hotchkiss ${ }^{[28]}$ showed that septic patients with multiple organ failure have an increased blood value of caspase-3. Most of the deaths in our study occurred as a consequence of multiple organ failure, but we did not observe any increase in intraperitoneal fluid levels of caspase- 3 in non-survivors.

To the best of our knowledge, this is the first clinical study to put forth the evaluation of peritoneal caspase- 3 in the decision-making process of repeated laparotomies in the treatment of secondary peritonitis.

Could intraperitoneal caspase-3 measurements within the initial $72-\mathrm{h}$ period provide some helpful information? The definitive answer is not yet known. What was found at the end of the study was a decrease within $72 \mathrm{~h}$ of caspase levels in comparison with the initial level in both survivors and in those having $\leq 4$ operations. Peritoneal fluid caspase levels seem to be altered during both the healing phase of the peritoneal inflammation and operative trauma. However, this altered peritoneal apoptotic response is not solely being regulated by endotoxin levels. ${ }^{[14]}$ More research is needed on the qualitative and quantitative properties not only of mast cells but also of other peritoneal cells in clinical peritonitis. 
The results of the present study may have been affected by the study design and the limited number of patients included. Those shortcomings should be taken into consideration while evaluating our findings.

In conclusion, second day APACHE II scores and age were found to be helpful in predicting disease severity and mortality. CRP, IL-6, leptin, cortisol, and peritoneal fluid samples for caspase-3 were not found to be helpful in discriminating the number of planned operations, even though there is a significant decrease in caspase-3 levels among surviving patients. The discriminative value of caspase- 3 for abdominal closure in planned relaparotomy should be evaluated in studies in which caspase-3 levels are monitored for a longer duration in a large number of patients.

\section{REFERENCES}

1. Wittmann DH, Schein M, Condon RE. Management of secondary peritonitis. Ann Surg 1996;224:10-8.

2. Schwartz SI, Shires GT, Spencer FC, Daly JM, Fischer JE, Galloway AC. Surgical infections. Principles of Surgery. 2005. p. 78-97.

3. Agalar F, Sayek I, Agalar C, Cakmakçi M, Hayran M, Kavuklu B. Factors that may increase morbidity in a model of intra-abdominal contamination caused by gallstones lost in the peritoneal cavity. Eur J Surg 1997;163:909-14.

4. Agalar F, Eroglu E, Bulbul M, Agalar C, Tarhan OR, Sari M. Staged abdominal repair for treatment of moderate to severe secondary peritonitis. World J Surg 2005;29:240-4.

5. Wittmann DH. Staged abdominal repair: development and current practice of an advanced operative technique for suppurative peritonitis. Acta Chir Austriaca 2000;32:171-8.

6. Hadeed JG, Staman GW, Sariol HS, Kumar S, Ross SE. Delayed primary closure in damage control laparotomy: the value of the Wittmann patch. Am Surg 2007;73:10-2.

7. Wittmann DH. Operative and nonoperative therapy of intraabdominal infections. Infection 1998;26:335-41.

8. Lamme B, Boermeester MA, Belt EJ, van Till JW, Gouma DJ, Obertop H. Mortality and morbidity of planned relaparotomy versus relaparotomy on demand for secondary peritonitis. Br J Surg 2004;91:1046-54.

9. Rakić M, Popović D, Rakić M, Druzijanić N, Lojpur M, Hall BA, et al. Comparison of on-demand vs planned relaparotomy for treatment of severe intra-abdominal infections. Croat Med J 2005;46:957-63.

10. Opmeer BC, Boer KR, van Ruler O, Reitsma JB, Gooszen $\mathrm{HG}$, de Graaf PW, et al. Costs of relaparotomy on-demand versus planned relaparotomy in patients with severe peritonitis: an economic evaluation within a randomized controlled trial. Crit Care 2010;14:97.

11. Agalar F, Hamaloglu E, Daphan C, Tarim A, Onur R, Renda $\mathrm{N}$, et al. Effects of $\mathrm{CO} 2$ insufflation and laparotomy on wound healing in mice. Aust N Z J Surg 2000;70:739-42.

12. Daphan CE, Agalar F, Hascelik G, Onat D, Sayek I. Effects of laparotomy, and carbon dioxide and air pneumoperitoneum, on cellular immunity and peritoneal host defences in rats. Eur J Surg 1999;165:253-8.

13. Agalar F, Sayek I, Cakmakçi M, Hasçelik G, Abbasoglu O.
Effect of omentectomy on peritoneal defence mechanisms in rats. Eur J Surg 1997;163:605-9.

14. Chung CS, Song GY, Moldawer LL, Chaudry IH, Ayala A. Neither Fas ligand nor endotoxin is responsible for inducible peritoneal phagocyte apoptosis during sepsis/peritonitis. J Surg Res 2000;91:147-53.

15. Kolaczkowska E, Koziol A, Plytycz B, Arnold B, Opdenakker G. Altered apoptosis of inflammatory neutrophils in MMP-9-deficient mice is due to lower expression and activity of caspase-3. Immunol Lett 2009;126:73-82.

16. Santamaría B, Benito-Martin A, Ucero AC, Aroeira LS, Reyero A, Vicent MJ, et al. A nanoconjugate Apaf-1 inhibitor protects mesothelial cells from cytokine-induced injury. PLoS One 2009;4:6634.

17. Knaus WA. APACHE 1978-2001: the development of a quality assurance system based on prognosis: milestones and personal reflections. Arch Surg 2002;137:37-41.

18. Koperna T, Schulz F. Prognosis and treatment of peritonitis. Do we need new scoring systems? Arch Surg 1996;131:1806.

19. van Ruler O, Mahler CW, Boer KR, Reuland EA, Gooszen HG, Opmeer BC, et al. Comparison of on-demand vs planned relaparotomy strategy in patients with severe peritonitis: a randomized trial. JAMA 2007;298:865-72.

20. Silvestre J, Póvoa P, Coelho L, Almeida E, Moreira P, Fernandes $\mathrm{A}$, et al. Is C-reactive protein a good prognostic marker in septic patients? Intensive Care Med 2009;35:909-13.

21. Prieto MF, Kilstein J, Bagilet D, Pezzotto SM. C-reactive protein as a marker of mortality in intensive care unit. Med Intensiva 2008;32:424-30. [Abstract]

22. Faggioni R, Feingold KR, Grunfeld C. Leptin regulation of the immune response and the immunodeficiency of malnutrition. FASEB J 2001;15:2565-71.

23. Bracho-Riquelme RL, Reyes-Romero MA, Pescador N, Flores-García AI. A leptin serum concentration less than $10 \mathrm{ng} / \mathrm{ml}$ is a predictive marker of outcome in patients with moderate to severe secondary peritonitis. Eur Surg Res 2008;41:238-44.

24. Wortel CH, van Deventer SJ, Aarden LA, Lygidakis NJ, Büller HR, Hoek FJ, et al. Interleukin-6 mediates host defense responses induced by abdominal surgery. Surgery 1993;114:564-70.

25. van Berge Henegouwen MI, van der Poll T, van Deventer SJ, Gouma DJ. Peritoneal cytokine release after elective gastrointestinal surgery and postoperative complications. Am J Surg 1998;175:311-6.

26. Riché F, Panis Y, Laisné MJ, Briard C, Cholley B, BernardPoenaru O, Graulet AM, et al. High tumor necrosis factor serum level is associated with increased survival in patients with abdominal septic shock: a prospective study in 59 patients. Surgery 1996;120:801-7.

27. Catalan MP, Esteban J, Subirá D, Egido J, Ortiz A; Grupo de Estudios Peritoneales de Madrid-FRIAT/IRSIN. Inhibition of caspases improves bacterial clearance in experimental peritonitis. Perit Dial Int 2003;23:123-6.

28. Hotchkiss RS, Swanson PE, Freeman BD, Tinsley KW, Cobb JP, Matuschak GM, et al. Apoptotic cell death in patients with sepsis, shock, and multiple organ dysfunction. Crit Care Med 1999;27:1230-51. 